\title{
TEACHING SPEAKING THROUGH DIALOGUES, DISCUSSIONS, AND ROLE-PLAYS
}

\section{[VYUCBA ZRUCNOSTI HOVORENIA POMOCOU DIALOGOV, DISKUSII A HRANIA ROLI]}

\author{
Klaudia Paulikova
}

doi: 10.18355/PG.2018.7.1.18

\begin{abstract}
The main aim of the article is to clarify the phenomenon of teaching speaking from a historical and contemporary point of view. The article focuses on three chosen contemporary teaching techniques - discussions, dialogues and role-plays in the context of both theory and practice by conducting action research with the application of two research methods - observation and interview.
\end{abstract}

\section{Key words}

teaching speaking, role-plays, discussions, dialogues, teaching techniques

\begin{abstract}
Anotácia
Úlohou práce je objasnit' fenomén vyučovania rozprávania z pohl'adu historického a súčasného. Ciel’om článku je priblížit tri vybrané súčasné techniky vyučovania - diskusie, dialógy a hranie rolí v teoretickom i praktickom kontexte pomocou akčného výskumu a aplikovaním dvoch výskumných metód - pozorovania a rozhovoru.

Kl’účové slová

vyučovanie rozprávania, hranie rolí, diskusie, dialógy, techniky vyučovania
\end{abstract}

\section{Introduction}

Speaking as a phenomenon of communication is one of the most important aspects of language. It not only enables the users to communicate the desired message to a wanted audience, but also stands as the means of relationship building, facilitates the establishment and protection of culture and values of specific groups or societies, and helps the communication on a worldwide scale. Even though many authors agree that teaching speaking, especially that of the second and foreign languages, used to be neglected by the teachers to a great extent, Howatt and Smith (2014) admit that the current teaching trends have been heading towards promoting teaching speaking as much as it is possible.

Supporting this, the current studies show that mastering communication in an oral form has become the most important part of the foreign language education with all its aspects. Therefore it gradually is becoming the essential issue to be dealt with within the lessons of foreign languages by the teachers themselves (Lawtie, 2004). A close study into the 
phenomenon allows us to find out how exactly has teaching speaking been dealt with throughout the course of history and examine some of the best working techniques and activities to promote its development in a real classroom.

\section{Teaching speaking from a historical and contemporary viewpoint}

Even though teaching speaking has always existed, no past records show that there would have been an independent section for education dealing exclusively with the matter of speech production and its mastering until the modern days. Studies show that the phenomenon had existed as a separate branch of L2 and foreign language education only since the 1980s when it emerged as an autonomous and independent division for teaching, learning and testing a language (Carter and Nunan, 2001).

The authors Carter and Nunan (2001) further give details about the three basic reasons for the study of speaking not developing until these times: tradition, technology, and exploitation. When considering the tradition of language education, it is evident that translational grammar methods have had a great impact on the strategies of teaching with the tendency to minimize the focus on communication skills. The sudden increase of various technological innovations enabled the teachers, linguists, and methodologists to study the features of talk. Due to its difficulty, though, it appeared to be a more convenient way for attention to be concentrated on written language more than spoken discourse when it came to production skills.

Although many other approaches later used oral communication as a means of their methodology, the speaking skill was not used in its own right for production of speech, rather as a means of language input, memorizing and habit building with instant corrections. The exploitation of the skill was mostly connected with pronunciation drills and a very small amount of spoken interaction at the very ends of lessons (ibid., 2001). Howatt and Smith (2014) include the translational grammar method into the Classical Period of language teaching, being one of the first methods used in modern language education throughout Europe. The basics of it lied solely in translations from one language to another. Moreover, as Howatt (1984) explains, the emphasis in the traditional methods was put merely on the comparison of L1 and L2, thus giving no space for the learners to experience the aspects of a foreign language on its own. As a result, Scrivener (2005) adds that there was very little use of the target language in speaking.

After understanding that the GTM and the use of tape recorders to find the links and differences between L1 and L2 were not appropriate enough for teaching communication, a new methodological standpoint - The Reform Movement emerged. Within The Reform Movement, there were some approaches and methods which offered an apparent perspective of oral skills teaching and marked its further development. As examples, the Berlitz Method, the Direct Method or the Natural Method could be mentioned. These methods focused their attention mainly on the retelling of a written text (Howatt and Smith, 2014). 
In the subsequent decades, a Scientific Period of language teaching took over, bringing forth approaches as Audiolingualism or the Oral Approach. The main ideas of the period were marked in a scientific approaching to language teaching, which had a great influence on FLE between the 1930's and 1960's (Richards and Rogers, 2014). These methods, as Carter and Nunan (2001) clarify, concentrated mostly on input before the output and the speech production was mainly focused on repetition, development of grammar, phonology and the fluency of learners.

Carter and Nunan (2001) further add, that later, when foreign language education started to be influenced by socio-linguistic and cognitive theories, the idea of Audiolingualism's and similar approaches' benefits on speech production was slightly transformed. Specialists found out that there were some crucial elements missing from the proper education of spoken discourse. It was the lack of connection between the language and meaning and the inability to provide a social context filled with functional aspects. As a consequence, a Communicative approach appeared.

It may be described on two levels. The first level, the national level, has paid attention to the notion of the interaction: introduction, invitation, offers, requests, apologies, etc. The second aspect of the communicative approach, the learner-centered one, put emphasis on the learner's needs and desires to communicate. One major disadvantage of these two aspects was that none of them had roots in a study of naturally occurring L2 discourse (Carter and Nunan, 2001).

That was, however, changed when the idea of Task Based Learning appeared. Even though Scrivener (2005) marks the Task-Based Learning into the Communicative Period, it possesses some specific features, which make it the most attractive methodology to be used according to the current needs. As Howatt and Smith (2014) explain, linguists and scientists started the examination and analysis of L1 discourse, which, as a consequence became the basis for the study of spoken discourse in the foreign language education. Not only have they discovered some specific features of the spoken communication that are not present in any of the basic communication skills, but also found the problem causing elements, which distract the learners from using L2 fluently and accurately. The task-based learning, therefore, has provided the linguists, methodologists, and teachers with new possibilities of further development of speaking in foreign languages (Carter and Nunan, 2001).

Considering the huge variety of approaches and techniques used in the current day and age, the overall flow of the education process may be adjusted according to the most trendy approaches or determined by the national curriculum, school or even teachers deciding about the most appropriate and effective ways of teaching. The success of the education of foreign languages does not however solely lie in the use of one or another method. Scrivener (2005) admits that teachers, even though inclining to taskbased learning the most, nowadays use a mixture of approaches and techniques, which are chosen and adjusted according to their own experience in the classrooms. As the main aims of teaching techniques are motivation, 
help in the development of critical thinking and facilitation of the learning process in order to prepare the learners for the ability to use the language beyond the borders of the classroom (Pokrivčáková, 2013), it is vital for the teachers to find and implement such approaches in their foreign language education that meet these criteria and are beneficial for the development of learners' skills.

When it comes to the use of specific activities for the development of speaking in the foreign language, it is important for the teachers to define whether the techniques meet the criteria for successful activity. Ur (1996) outlines these in high participation, adequate language level, a lot of talking and high motivation among the participants. Moreover, it is important to set the main objectives of the activities. As Brown (2004) states the use of approaches, techniques, and activities for speaking should be based on a precise planning of the field of focus - the control over the activity, whether it is aimed at speaking individually, in pairs, or groups and if the attention is paid to the practice of accuracy, fluency or other feature of speech in a foreign language. Moreover, Scrivener (2005) and Harmer (2001) mark the teachers' importance of knowing all the strengths and weaknesses of their classes in order to be able to guide the lessons effectively towards success with the use of appropriate activities.

\section{Dialogues, role-plays and discussions}

There is a large number of activities designed for the purposes of development of speaking in the foreign language, and the choice of the appropriate and most beneficial ones is one of the most important procedures the teachers are obliged to undergo during the process of planning their lessons. Effective speaking activities should not only make the learners retrieve formerly gained knowledge but also guide and prepare them for real communication beyond the class (Harmer, 2012). The activities chosen for the current study were dialogues, role-play and discussions.

Getting an insight into dialogues in FLE, it can be stated that they are a very frequently used activity in teaching speaking. They usually involve two learners, whose task is to perform a short conversation according to the instructions given (Bygate, 1987). As it is mentioned in Pokrivčáková (2013), there is a variety of dialogue types - controlled, guided and free, which all carry importance for the practice of specific features of speaking. Thornbury (1995) moreover adds that the importance of dialogues lies in the fact that they have a tendency to mirror interactions with the real world, which becomes an essential factor for language education.

Role-playing, as a technique of practicing situations, scenarios or problems with roles for the students creates a safe environment for practicing the foreign language. It includes the issues of what to say, how to react or what to do under specified conditions (McGuire, n.d.). Role-plays are mostly 
designed for working in pairs or small groups and due to the fact that they are intended to simulate situations in everyday life, they are considered to be one of the most powerful activities for bridging the occurrences of the artificial circumstances of the classroom with real life beyond it (Bygate, 1987; Ur, 1996). In addition to that, they develop intercultural communicative competence, which is found essential for the ability of communication with people of other cultures (Reid, 2015).

Discussions are free speaking activities that either involves larger groups of students or a whole class. They promote the learners to share their beliefs, emotions or standpoints towards various kinds of topics (Lightfood, 2010). Ur (1996) marks their huge success in foreign language education due to the fact that they are very similar to interaction in real life; therefore she highly recommends using discussions in the classrooms as frequently as possible.

\section{Researching an existent classroom}

In order to obtain real and authentic information about the realities of using the formerly mentioned speaking activities, a decision to conduct action research at a local language school with adult learners was made. There were two basic research aims stated for dealing with the issue:

- finding out what ways for improvement of the teaching process of the development of speaking did the three activities - dialogues, role-plays and discussions offer in the teaching process.

- finding out whether the activities implemented were beneficial for both the learners and the teaching process and whether there were any suggestions for further improvement of the lessons.

The research questions were, therefore, stated as follows:

1. How may the speaking skill of learners of English be improved by the use of dialogues, discussions and role-plays?

2. What are the reflections on the collected data and suggestions for future improvement?

\section{Planning phase}

In the first phase of action research, the most important points - what the field for improvement was, why the action was going to be done and what actions were needed to be carried out in order to conduct the study successfully were needed to be clarified. The reason for conducting action research in the current study was the intention to improve the quality of lessons by developing the learners' communicative competence. Even though the lessons chosen to be examined were considered to be quite successful, a long-term observation had shown that many times they seemed flat and not challenging enough for the learners because the materials and exercises in their course books were not providing enough variety of activities for 
speaking. In the planning stage, the main facts were stated - the learners did not get enough variety of activities for improving their speaking skills, and there was a need for more speaking activities to get the learners motivated to speak and to improve their speaking skills - fluency, accuracy, and confidence. There was an intention to make them think in English more because many times they could not say something due to the fact that they were creating it too difficultly in their minds in their mother tongue

\section{Action}

According to the information gathered from the phase of planning the main action was done. The researcher chose three activities to be implemented into the lessons - free discussions, role-plays, and dialogues - answering questions under a time limit. The researcher's primary aim was, by implementing the activities, to find out whether they were beneficial for the development of speaking in a foreign language and if so, how they helped the learners in mastering those aspects of speech in the foreign language, which they had the greatest difficulties with. The process of the action in research lasted for two months, and the activities were repeatedly implemented in two groups of learners. The activities were adapted to the corresponding topic and unit from the course books.

\section{Observation}

Simultaneously with the implementation of activities into the lessons an observation was carried out. While the activities were ongoing, the researcher was observing all the happenings and making notes for further evaluation. The observation focused on whether the learners found the activities interesting and motivating for speaking, whether the activities developed confidence, accuracy, fluency and overall complexity of speech, and whether the learners switched to their mother tongue while performing. Subsequently to observation, all the collected data were processed, and the activities were evaluated.

\section{Reflection}

The last phase focused on reflecting the outcomes collected in the study. Its main aim was finding out whether the activities implemented throughout the study were successful. The reflection involved the method of interview. With the use of an informal, conversational interview conducted with the learners the researcher aimed at finding out whether there were any suggestions for the future improvement of lessons in terms of the development of speaking. The interview was involved into the course of two lessons; the last several minutes of one lesson were devoted to an interview with one of the groups, and another lesson's several minutes to the second group of learners. Subsequent to the interview the data collected were evaluated, and an overall conclusion was made.

\subsection{Research Sample}


The research sample was chosen according to the workplace of the researcher. The place was a language school situated in Nitra, Slovakia and the sample chosen for research were two groups of adult learners. Both of the groups consisted of six students. The first research group, Group A, were learners of the level A2 according to CEFR, and their placement within the language school and the course book they used was Pearson's Speak out Elementary. The second group of learners, Group B, was of level B1 according to CEFR and the course they attended and the course book they used was Pearson's Speak out Intermediate. Both of the groups had four lessons a week in the language school, divided into two days of the week.

\section{Implementation of Activities into Teaching Process}

The phases of the research procedure dealt with establishing such circumstances for the learners of English within the education in the language school, which would provide them with new opportunities for the development of their speaking in the foreign language. The researcher implemented the speaking activities through the course of two months repeatedly. Their duration was $20-25$ minutes on average and their aim was to find suitable solutions for the elimination of the difficulties the students were concerned with according to the experience from the lessons. Moreover, finding out how the techniques could contribute to the development of the learners' speaking competence in the foreign language was also one of the aims of the survey.

\subsection{Free Discussions}

Even though almost all the participants claimed that they had experienced enough everyday world-like discussions at their foreign language lessons, they also admitted that it was one of the most important issues for them to be able to communicate in the foreign language in the real world - outside the classroom about topics they might not normally meet in the course books of English. For that reason, and upon their request, the researcher decided to implement free speaking discussions opportunities into the lessons. The learners' communicative skills were tested in everyday life topics without the possibility for them to do any preparations and plans for what and how to say something. The basic aim of this activity was to find out whether the learners were able to speak in the foreign language without any previous input of information spontaneously and without difficulties. The possibility of turn-taking allowed them to react instinctively without long preparation, thus providing them with conditions very similar to conversations beyond the classroom. The secondary goal of the discussions was finding out, what possible improvements they could make in the aspects of speech.

\section{Action and Observation}


The researcher started the activity by suggesting a discussionn topic, such as weather, travelling, leisure time, etc., or asked a controversial question to be discussed (e.g. Do you believe in the benefits of alternative medicine?) The learner's task was to discuss the given statements or topics as a whole class discussion. They started expressing their opinions and standpoints towards the suggested issues very eagerly. They seemed very happy to be able to talk about topics close to their lives beyond the artificial arrangement of the classroom. They took turns in speaking and contributed to the flow of the conversation freely without being pushed by the researcher to answer. Stronger learners, however, reacted more often than the others. Therefore the weaker ones were asked to share their opinions, as well. The group A showed some difficulties in speaking freely, as they had not experienced activities like that before and seemed confused and a little stressed not to have any given patterns according to which they could speak, as they usually did in the course book. Their speech was slow; therefore the pace of the whole activity was also very slowed down. But due to the friendly environment of the classroom and the positive approach of the teacher, they got used to the activity very quickly and performed it with joy. It was obvious that they were waiting for the teacher to correct all their mistakes as they were speaking at the very beginning of the activity, but soon they realized that it was not the main aim. A few minutes after they were speaking freely and did not care about their mistakes. They often stopped because they were searching words or they even switched to their mother tongue. The continual repetition of the activity made them more confident in speaking, and even though there were still big deficiencies in vocabulary and grammar, their speed of speaking got much better. When one learner did not know how to say something, the others helped them with the vocabulary and correcting mistakes.

The group B did not show any difficulties in speaking from the very beginning of the activity. They enjoyed it so much that many times they bent from the original discussion topic to something completely different (e.g., from the topic petty crime the discussion got to the description of the story of kidnapping a girl in Nitra). The researcher, naturally, did not stop the learners. The activity also stretched in time. Even though the learners showed some minor difficulties with expressing themselves accurately, their peers were often very helpful and provided them with the specific expressions or words.

\section{Findings and Reflection}

It has been found out that the activity of free discussions was a very successful complement to the lessons of English within the language school. It not only helped the learners to feel less distressed about using grammatically accurate structures but also as highly motivating for speaking. The free discussions were the only opportunity for the learners to express their own thoughts and opinions, which made the lessons more enjoyable and relaxed. Not to mention the fact that due to this activity a better socializing of the classmates was able to occur, which helped the learners in breaking barriers and building a more friendly and familiar environment for learning, 
thus allowing the learners to speak openly without any restrictions or fears. To refer to the difficulties dealt with in the first phase of the study, it can be stated that free discussions were found extremely beneficial in terms of improving fluency. In the course of the repetitive lessons dealing with free speaking, the researcher noticed positive changes in the length of learners ${ }^{\text {ee }}$ utterances, in taking a shorter time for thinking and also natural improvement of their scope of vocabulary. Even though the participants had the tendency to switch to their mother tongue in some cases, the free discussions enabled the learners to think critically and boost not only their confidence but also fluency in the target language. The advantages and disadvantages of the activity are shown in the table below.

\section{Tab. 1 -Free Discussions}

\begin{tabular}{|l|l|}
\hline \multicolumn{1}{|c|}{ Benefits } & \multicolumn{1}{c|}{ Deficiencies } \\
\hline - Motivating & $\begin{array}{l}\text { - The tendency to switch to mother } \\
\text { tongue }\end{array}$ \\
\hline - Interesting and relaxing & \\
\hline - Develop fluency & \\
\hline - Help in improving confidence & \\
\hline $\begin{array}{l}\text { - The input of vocabulary from } \\
\text { more sources }\end{array}$ & \\
\hline - Boost critical thinking & \\
\hline
\end{tabular}

\subsection{Role-plays}

Despite the fact that role-plays had been introduced to the lessons of English within the language school before the particular research, their importance was marked during the study of the theoretical information. Due to this fact, and the fact role-plays appear to be extremely beneficial in preparing the learners for real situations beyond the classroom, the researcher decided to apply these activities with the intention to test their qualities. They were applied three times for Group A, and the topics they covered were various (ordering meals in a restaurant, shopping for clothes, making arrangements for the evening). Group B also performed the activity three times through the course of the study (with the topics of clarifying opinions, making complaints and dealing with misunderstandings). The main aims were providing the learners with other possibilities for practicing given structures and patterns that were present in the course book and finding out, which of the aspects of speech the activity was beneficial for.

\section{Action and Observation}

The role-plays were designed and prepared according to the topic of the lesson. The researcher distributed the previously prepared role cards to the learners and asked them to read their roles precisely for themselves. The learners did it, and when they did not understand some vocabulary or task, they were explained it by the researcher. After reading, they were asked to prepare the performance of their role, which took them two-three minutes. Slavonic Pedagogical Studies Journal, ISSN 1339-8660, eISSN 1339-9055, Volume 7 Issue 1, February 2018 
When the tasks were clear, and the preparations were ready, the researcher asked the learners to perform their roles with a partner. There were three roleplays ongoing at the same time, and the researcher was walking around and monitoring the performances. The participants showed no major difficulties in performing role-plays. The given tasks to use specific linguistic structures were completed and fulfilled by all the learners. The atmosphere of the lesson during the activity was relaxed, so the learners felt comfortable and excited to act out roles, which they might normally not do in real life. The learners were acting their roles out eagerly and with joy. They were paying much attention to creating meaningful, grammatically accurate speeches, which took them a longer time of focusing on what and how to say. They were listening to their partners' responses and were very enthusiastic about being able to respond to them, as well. When the performance of the pairs was done, the learners were asked one by one to perform their role-plays with their partners in front of the rest of the classroom. The second performance was more relaxed and smooth than the first one, even though some of the learners altered it from their first role-play to a certain degree. Looking at the activity from the perspective of the two groups, there were no major differences between them. The only difference was in the length of the activity, as the learners of Group A needed more time for preparation and the overall performance lasted longer than of those of the Group B.

\section{Findings and Reflection}

Role-plays have been found to be very beneficial for practicing a given target language. They were not only enjoyable for the learners due to the fact that they had to act out situations they might not get to on their own, but the activity was also easy to be performed, as the roles for each of the participants were specified in advance. In each case the role-plays allowed the students to practice the previously learned structures, which became a very good basis for practicing, storing and further recalling of the formerly gained knowledge in the foreign language.

The possibility of the performance for two times (once with a partner and second time in front of the whole classroom) gave the learners not only a chance to practice accuracy but also to perform more confidently and fluently. A genuine preparation for acting the roles out helped the learners in improving their overall ability of produce complex, and also fluent speeches. Linking the issues depicted in the first part of the research, it can be stated that role-plays were found beneficial from more perspectives. They help in the development of accuracy, fluency, confidence, complexity of speech and provide the learners with possibilities for getting prepared for real-life situations. The benefits are listed in the following table.

Tab. 2-Role Plays

\begin{tabular}{|l|l|}
\hline \multicolumn{1}{|c|}{ Benefits } & Deficiencies \\
\hline - Build confidence in speaking & \\
\hline - Develop accuracy & \\
\hline - Develop fluency & \\
\hline
\end{tabular}

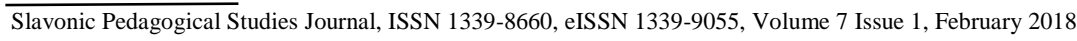




\begin{tabular}{|l|l|}
\hline - Develop complexity of speech & \\
\hline - Prepare learners for situations beyond the classroom & \\
\hline
\end{tabular}

\subsection{Dialogues - Answering Questions under Time Limit}

This activity was developed by the researcher herself as a kind of dialogue. The aim was to find out whether it could provide the participants with any help in preparation for conversations beyond the classroom. By creating real life-like situations in the classroom with not too much time for thinking and organizing words into correct patterns the researcher aimed at the issue, whether the learners could master answering to each other promptly without delays and difficulties. The activity was implemented into five of the examined lessons for each of the two groups, and the duration was twenty minutes on average.

\section{Action and Observation}

A set of questions was prepared for pairs of learners. Cut into strips, the questions were laid facing down, and the learners were asked to prepare a cell phone with a stopper watch on it. They have explained the rules: One of the pair chooses a question, reads it aloud and sets the stopper to the given time limit (one minute, forty seconds, twenty seconds). Their partner's duty is to fulfill the task - answer the question under the given time limit. After that, they switch roles and the one who answered first picks a question for their partner. The learners were taking turns in asking and answering very excitedly. Even though they found the activity a little confusing at first, (as they were concentrating on the perfect placement and use of words and structures in order to avoid mistakes and reach as accurate speeches as possible), they quickly understood what the main aim of the activity was - to fulfil the task of answering a question in time even if with mistakes. After a short time from the desire to say something completely accurately, they switched to willing to fulfill the task. The shortened time limit created more challenge for the learners, so the tendency to answer with no mistakes completely disappeared. At the very beginning of the activity, the learners were told that the time limit was one minute. They found it quite enough, so the researcher shortened it to forty seconds, and then to twenty seconds. The learners of Group A, especially the weaker ones, had some minor difficulties with expressing their thoughts correctly in such a short amount of time. Moreover, both of the groups were heard to use their mother tongue when they did not know how to express themselves clearly, so instead of explaining (they did not have time for it) they simply said it in Slovak.

\section{Findings and Reflection}

It was found out that this particular type of activity is beneficial for the purposes of improving fluency and complexity of speech in performing in a foreign language. Due to the fact that the learners were asked to answer under the time pressure, they had less time to think about the appropriate use 
of grammar or vocabulary, which resulted in a spontaneous stream of speech production. The activity was moreover useful for the improvement of confidence in speaking, as every successfully answered question pushed the learner forward to achieve more. It is important to mention, however, that there were also some deficiencies connected with the activity. First of all, it did not practice accuracy at all. The second disturbing issue was switching into the mother tongue. Due to the fact that the learners experienced lack of vocabulary knowledge in certain areas, their tendency to switch to their mother tongue was strengthened by the pressure of time limit. When looking at the activity from the viewpoint of dealing with difficulties, it can be stated that answering questions under a time limit is very beneficial for developing fluency and overall complexity of speech and enhancing the confidence of learners. The table below summarizes the benefits and deficiencies of the activity.

Tab. 3-Answering Questions under Time Limit

\begin{tabular}{|l|l|}
\hline \multicolumn{1}{|c|}{ Benefits } & \multicolumn{1}{c|}{ Deficiencies } \\
\hline - Develop fluency & $\begin{array}{l}\text { - The tendency to switch to mother tongue } \\
\text { due to time pressure }\end{array}$ \\
\hline - Boost confidence & - No focus on accuracy \\
\hline $\begin{array}{l}\text { - Develop complexity of } \\
\text { speech }\end{array}$ & \\
\hline
\end{tabular}

\section{Conclusion}

Looking at the implementation of activities into the teaching process from the researcher's point of view it can be stated that the overall process was very successful. The variety of speaking opportunities made the lessons more interesting and motivating for both the learners and the researcher herself. New possibilities for developing speaking skills emerged, which were all covered by the chosen activities. Role-plays were, for example, found extremely beneficial for the development of accuracy. Fluency, on the other hand, was found to be best developed by answering questions under a time limit and free discussions. Confidence in speaking was boosted by almost all the implemented activities. For thinking in English, the best ways were using free discussions. The overall complexity of speech was found to be developed by the use of answering questions under a time limit and roleplays. Moreover, it was found out that free discussions and role-plays are a great source for preparing the learners for real-life situations. As a result, it can be assumed, that the implementation of these activities into the lessons more frequently can contribute to eliminating speaking problems the learners are likely to experience throughout their language studies.

\section{Learners' Reflections and Suggestions for Future Improvement}

The effectiveness of the activities for improving the learners' speaking skills has been proven by observation of the lessons. But whether guiding lessons with the tested amount of activities was found enough for the 
learners themselves, was a question of further investigation. For that reason, the researcher decided to interview her learners, as part of the last phase of action research with the aim of finding out whether they were satisfied with the activities implemented and whether they had any suggestions for improving the quality of lessons in the future. These can be found in the following table.

Tab.7 - Suggestions for improvement

\begin{tabular}{|l|}
\hline \multicolumn{1}{|c|}{ Participants' suggestions on future improvement } \\
\hline - Implement discussions about real life into every lesson \\
\hline - Use whole class debates/discussions \\
\hline - Implement more role-plays into more lessons \\
\hline - Concentrate more on grammar \\
\hline - Concentrate more on vocabulary \\
\hline - Implement more variable topics into the lessons \\
\hline
\end{tabular}

First of all the learners stated that they were completely satisfied with the variety of activities used throughout the study. They admitted that they had noticed some changes on their own speaking in a foreign language, which were visible in feeling more confident and being able to react more spontaneously. As for improving the quality of education for the development of their speaking, the learners suggested implementing free discussions about real life into every lesson. They reasoned it by the importance of being able to communicate about everyday life topics beyond the classroom, which they had lacked in their lessons before the study took part. They also suggested having whole class discussions instead of working in pairs, as they claimed that they were very likely to make mistakes which were many times overheard and not corrected by the teacher because she could not listen to all the pairs at the same time. They asked for using more role-plays because they found these activities very helpful and beneficial for the development of their overall speaking abilities. Some of the learners suggested implementing speaking activities focusing solely on grammar or vocabulary, which would be difficult to be learned by traditional methods. Lastly, they suggested using higher variability of themes on the lessons, as many times the topics determined in the course book were found very boring for them and they complained that some activities took too long. The suggestions of the participants were processed into a table for a better view.

\section{Bibliographic references}

BROWN, H. D. 2004. Language assessment principles and classroom practice. New York: Pearson Education, 2004. 324 p. ISBN 0130988340

BYGATE, M. 1987. Speaking. 1st ed. Oxford: Oxford University Press, 1987. 121 p. ISBN 9780194371346

CARTER, R. - NUNAN, D. 2001. The Cambridge Guide to Teaching English to speakers of other languages. 1st ed. New York: Cambridge University Press, 2001. 294 p. ISBN 9780511500428 
HARMER, J. 2012. Essential teacher knowledge: core concepts in English language teaching. 1st ed. Pearson Longman, 2012. 287 p. ISBN 9781408268049

HARMER, J. 2001. The practice of English language teaching. 3rd ed. England: Longman, 2001. 371 p. ISBN 9780582403857

HOWATT, A. P. R. 1984. A history of English language teaching. 1st ed. Oxford University Press, 1984. 394 p. ISBN 978019437052

HOWATT, A. P. R - SMITH, R. 2014. The history of teaching English as a foreign language, from a British and European perspective. In Language and History [online]. 2014. [cit 2017-01-07]. Available online: http://www.tandfonline.com/loi/ylhi20

LAWTIE, F. 2004. Teaching speaking skills 2 - Overcoming classroom problems. In Teaching English [online]. 2004. [cit. 2017-02-21]. Available online: https://www.teachingenglish.org.uk/article/teaching-speaking-skills2-overcoming-classroom-problems

LIGHTFOOD, A. 2010. Group discussion skills. In Teaching English [online]. 2010. [cit. 2017-03-13]. Available online: https://www.teachingenglish.org.uk/article/group-discussion-skills

McGUIRE, D. n.d. Role-play method of teaching: Definition and benefits [online]. n.d. [cit. 2017-02-20]. Available online: http://study.com/academy/lesson/role-playmethod-of-teaching-definitionbenefits.html

POKRIVCAKOVA, S. 2013. Teaching techniques for modern teachers of

English. 1st ed. Slovakia: ASPA, 2013. 116 p. ISBN 9788089477104

REID, E. 2015. Techniques Developing Intercultural Communicative Competences in English Language Lessons. In Research Gate [online]. 2015. [cit. 2017-11-06]. Available online: https://www.researchgate.net/publication/277964393_Techniques_Developin g_Intercultural_Communicative_Competences_in_English_Language_Lesso ns

SCRIVENER, J. 2005. Learning teaching: A guidebook for English language teachers. 2nd ed. Macmillan ELT, 2005. 432 p. ISBN 9781405013994

THORNBURY, S. 1995. How to teach speaking. 1st ed. Pearson Longman, 1995. 156 p. ISBN 978058283591

UR, P. 1996. A course in language teaching: Practice and theory. 1st ed. Cambridge: Cambridge University Press, 1996. 375 p. ISBN 9780521449946

"The paper includes research results gained as a part of the project KEGA 006UKF-4/2017 Kontrastívna analýza ako efektívna podporná metóda vyučovania anglickej výslovnosti na ZŠ."

Mgr. Klaudia Pauliková

Department of Language Pedagogy and Intercultural Studies

Faculty of Education

Constantine the Philosopher University in Nitra

Dražovská 4, 94974 Nitra

Slovakia

Email: klaudia.paulikova@ukf.sk 